\title{
REGIONAL DIFFERENCES IN AGRICULTURE IN SLOVAKIA AFTER ITS ACCESSION TO THE EUROPEAN UNION
}

\author{
Jana Némethová, Marek CiváŇ \\ Department of Geography and Regional Development, Faculty of Natural Sciences, Constantine the \\ Philosopher University in Nitra, Nitra, Slovakia
}

Manuscript received: October 2, 2015

Revised version: January 18, 2017

\begin{abstract}
Némethová J., Civáñ M., 2017. Regional differences in agriculture in Slovakia after its accession to the European Union. Quaestiones Geographicae 36(2), Bogucki Wydawnictwo Naukowe, Poznań, pp. 9-21, 9 figs.

AвSTRACT: The Common Agricultural Policy of the European Union is reflected in the development of agricultural production in Slovakia. The development of livestock production faced significant changes reflected in its overall decrease. The decrease in the level of agricultural production in Slovakia between 2002 and 2010 is shown by several indicators assessed in this paper. Its main aim is to highlight differences in Slovak agriculture at the level of LAU I, which are districts of Slovakia, according to the selected indicators of agricultural production between 2002 and 2010. We analyse the development of regional differences in Slovak agriculture that have widened under the influence of the EU Common Agricultural Policy. The development of selected indicators of agricultural production was analysed using the change index, which best represents differences in the development of agriculture in the Slovak regions.
\end{abstract}

KEY WORDS: Common Agricultural Policy, Slovak agriculture, indicators of crop and livestock production, agricultural employment, regional differences

Corresponding author: Jana Némethová, Department of Geography and Regional Development, Faculty of Natural Sciences, Constantine the Philosopher University in Nitra, Trieda Andreja Hlinku 1, 94974 Nitra, Slovakia; e-mail: jnemethova@ukf.sk

\section{Introduction}

The changes that occurred in the agricultural production of Slovakia in the period from 2002 to 2010 were associated with the country's preparation and later accession to the European Union and the adoption of the EU Common Agricultural Policy (CAP) by the new member states. This policy significantly influences Slovakia's national agricultural policy. The accession enabled the country to draw yearly financial resources supporting agriculture, which should serve to increase its level and efficiency in general. There are important indicators of the level and performance of Slovak agriculture, such as its share in gross domestic product - showing a downward trend $(4.54 \%$ in $2002,2.87 \%$ in 2012$)$, or the share of employees in agriculture in overall employment $(5.06 \%$ in 2004, 2.93\% in 2012). Another relevant parameter is a crop to livestock production ratio. The share of livestock production in the aggregate volume of gross agricultural production was higher before 1990. The social, political and economic changes after 1990 altered this ratio and the proportion of crop production started to increase. Changes related to the implementation of the CAP after 2004 were also reflected in the overall development of crop and livestock production in Slovakia, while livestock production itself was hit by more significant changes that 
resulted in its decline. Its share in the aggregate volume of gross agricultural production reached $54.33 \%$ in 2002 , but dropped to $46.10 \%$ in 2010 . Livestock production prevailed over crop production till 2004, but Slovakia's accession to the EU changed this situation and the higher proportion in the aggregate volume of gross agricultural production became typical of crop production.

The development tendencies of agricultural structures as a consequence of the transformation of agriculture and the accession to the EU was an object of many geographical studies, such as Spišiak et al. (2005), Spišiak (2011), Spišiak, Némethová (2008), Némethová (2009a, 2009b, 2010), or Holúbek et al. (2013). Joining the EU caused the adoption of the CAP in the Slovak agriculture and the adaptation of its conditions to the EU common market. On the one hand, Slovak agriculture has to be competitive at this market, but on the other, there are unequal conditions across the whole EU, which is reflected in lower subsidies in the new EU member states in comparison with the other (old) ones. Slovak EU membership was reflected in higher government expenditure on agriculture and caused an increase in agricultural prices that became closer to those in the EU (Némethová et al. 2014). A comparison of CAP effects on the development of agricultural production - the volume and production of foreign trade according to EU-27 of 2004 - was made by Buday et al. (2012). The expected influence of the CAP on the development of agricultural production in Slovakia was studied by Falt'anová (2008), while Marušinec and Škriečka (2009) analysed the support system in agriculture. A detailed study of the effects of potential scenarios of the CAP after 2013 in Slovakia was presented by Uhrinčat'ová (2011). The impact of the transition period as well as that after joining the EU was reflected in the general use of farmland. A dilapidation of the cultural agricultural landscape became evident after 1989 as well as a progressive overgrowing of pastures and meadows by non-forest trees and shrubs. This became a problem of non-use of large-scale landscapes. Such overgrowing processes are especially a consequence of general stagnation in agriculture, especially in livestock production (Zaušková et al. 2012).

The effects of the CAP on the agriculture and countryside of the Czech Republic as well as regional differences have been explored by many authors (e.g. Střeleček et al. 2004; Kabrda, Jančák 2006; Věžník, Konečný 2011; Svobodová 2011; Svobodová, Věžník 2011; Věžník, Svobodová 2012; Král et al. 2012). The Czech agricultural sector has undergone many changes, not only the reduction of employees. Over the last 30 years, there has been a rapid decline in particular breeds of animals, a transformation of their structure and way of breeding and the structure of the general food sector (Věžník et al. 2013). Vaishar and Zapletalová (2009) highlight a growing role of agriculture as an element of landscape maintenance in the majority of border regions because those regions are usually characterised by unfavourable farming conditions.

Many foreign authors have compared structural changes in agriculture in various states after their joining the EU (Kulikowski 2005; Kołodziejczak 2006; Buchenrieder, Möllers 2009; Csaki et al. 2010; Kołodziejczak, Kossowski 2011, etc.). Buchenrieder and Möllers (2009) analysed the development of the countryside and compared structural changes in agriculture across selected new EU member states (Romania, Poland, Hungary, Bulgaria). The situation in Poland from the perspective of beneficiaries of the European funds was examined by Rudnicki (2013). On the other hand, Shucksmith et al. (2005) presented rural diversity in terms of demography and related indicators (e.g. the level of education, productive age of employees in agriculture) as well as the environmental aspect. They also concentrated on the different economic performance of rural areas (e.g. market principles, institutions, networks, organisations). According to the afore-mentioned authors, rural regions contribute to the quality of life because of their wide range of possibilities. Ramniceanu and Ackrill (2007) point out the strengthening position of the revitalisation of agriculture and its non-productive functions in the development of the countryside.

\section{Materials and methods}

The level of agricultural production in Slovakia and its regional differences during the period between 2002 and 2010 are assessed in terms of such indicators as the production of selected crops, the number of livestock units and their intensity, the number of employees in 
agriculture and their share in overall employment in Slovakia. The main goal of the paper is to analyse geographical differences in the development of agriculture in Slovakia at the LAU I level. The CAP not only did not diminish those inequalities, but they became even wider. Regional disparities in Slovak agriculture are also a result of historical development determined by various soil and climatic conditions. Different production and economic conditions in the agricultural sector have an impact on agricultural production in particular areas. The establishment of such regions is also determined by significant regional contrasts in the Slovak conditions (Gozora 2006 in Marcinčáková 2013). One of the main goals of the CAP is to support and sustain agricultural production in disadvantaged areas (e. g. mountainous, marginal areas, etc.). The importance of financial flows coming from the CAP is to ensure that rural communities located in areas most vulnerable to adverse impacts should maintain a good economic situation and do not vanish gradually (Common Agricultural Policy 2012). Despite the subsidy support from the CAP, regional differences in Slovak agriculture really exist. Here they are presented in terms of the mentioned indicators available at the level of districts (LAU I units) in the Statistical Office of the Slovak Republic.

The data used in this paper were obtained from the Regional Database at www.statistics.sk and the 2010 Farm Structure Census. The study period is that between 2002 and 2010. Structural changes that occurred in the Slovak agriculture then were analysed using the change index $\left(C_{i A-B}\right)$ between the two time periods (A, B). It shows a change in proportion in the area of a territorial unit $\left(P_{i}\right)$.

$$
C_{i A-B}=100 \times \frac{P_{i B}}{P_{i A}}
$$

$P_{i A}$ - proportion of $i$ category at the beginning of the reference period,

$P_{i B}$ - proportion of $i$ category at the end of the reference period.

This index can assume values from 0 to infinity, with $100 \%$ showing no change, higher values meaning an increase and lower ones (under $100 \%)$ a decrease in the indicator in question. The value of $0 \%$ shows that the selected element is not registered, while infinity (theoretically) means the absence of the element in a territorial unit at the beginning of the reference period (Bičík et al. 2010). This index was used to assess the dynamics of change in the development of agriculture in particular regions in Slovakia at the LAU I level, while the indicators of crop production and the number of livestock units revealed regional differences in agriculture.

\section{Results: development of the production of selected crops}

Slovakia's accession to the EU as well as the implementation of a new agricultural policy has brought significant changes in national agriculture in terms the sowing structure and the final volume. Mainly cereals are grown on arable land, which occupies about $59 \%$ of farmland in Slovakia. Cereal production was analysed in the districts of Slovakia before it joined the EU (2002) and after the accession (2010). Using the change index, we analysed cereal production pointing to a decline in production in almost all districts. Slovakia as a whole recorded a drop in production by $20.02 \%$ (a decrease of 639,363 tons). A decline higher than $50 \%$ was typical especially of districts located in the eastern and central parts (Fig. 1). Growth was recorded in the Kysuce region and in some districts of western Slovakia, which is the most agricultural region. The districts in western Slovakia on the Podunajská nížina (the Danube Lowland), where granaries are located, recorded only a slight decline in production compared with those in southern and eastern Slovakia. The most popular crops are wheat and barley (especially malting and fodder varieties). Considering their widespread use (e.g. the production of bio-fuels, food and fodder) an increase is expected in areas under these crops. Global warming may cause their cultivation in all natural regions of Slovakia as well as in areas at higher altitudes.

The second most popular group of crops is oilseeds, which are of great interest on the agricultural market because of their use not only as food, but currently also as energy crops. The cultivation of oilseeds is supported by the EU in the form of direct subsidies. Every year their share in the structure of the cropland area as well as 


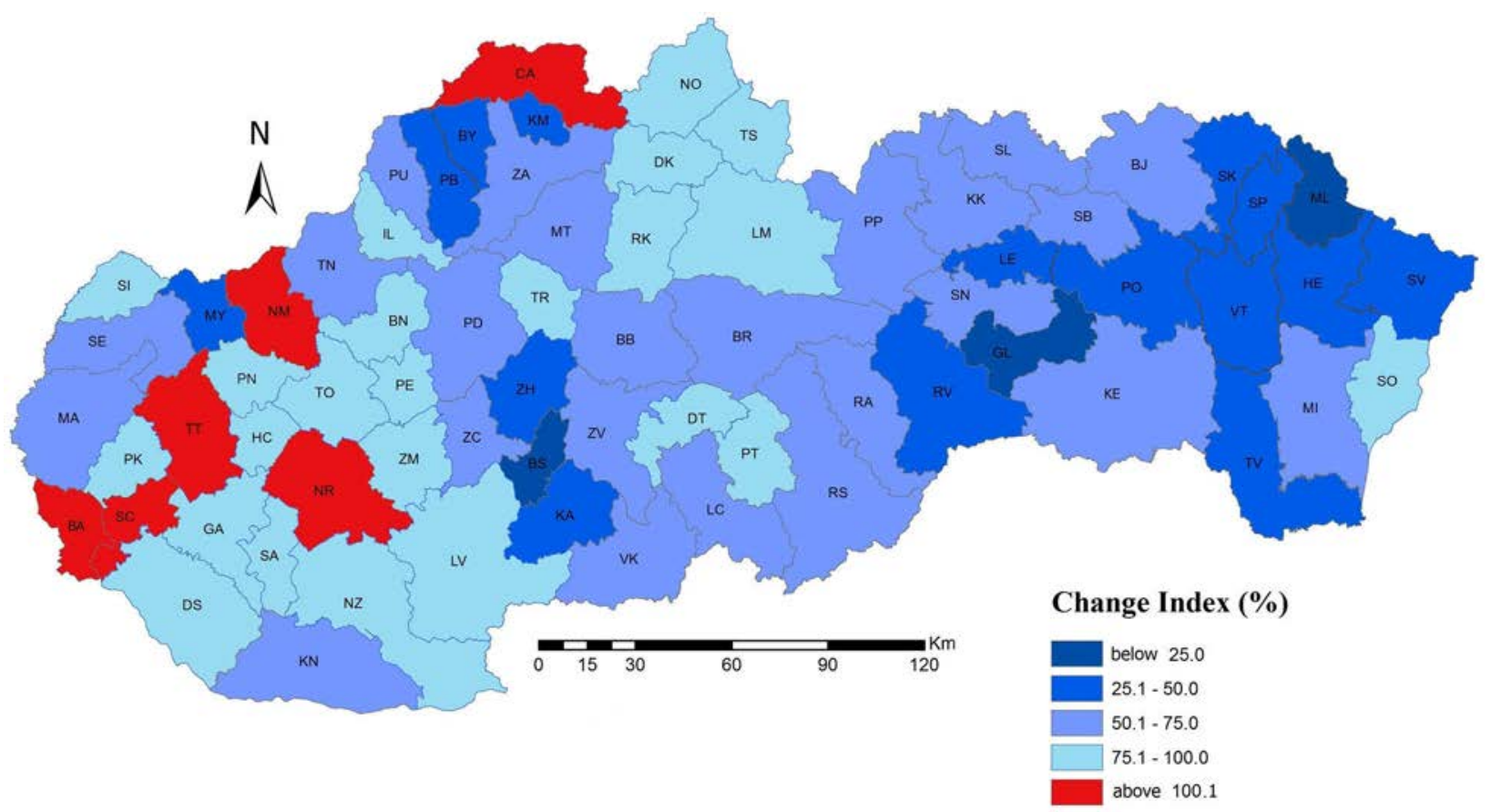

Fig. 1. Development of cereal production in the districts of Slovakia in 2002 and 2010.

Source: regional branches of the statistical office of the Slovak Republic in Nitra, Farm Structure Census 2010, own elaboration.

their production increases. During the reference period, its production increased by $26.89 \%$, or 106,113 tons. As for oilseed production, in most districts an increase occurred according to the change index. This increase concerned districts where the crop is grown the most. Those are the regions on the Podunajská nížina (the Danube Lowland), Juhoslovenská kotlina (the Southern Slovak Basin) and Východoslovenská nížina (the Eastern Slovak Lowland). In the north, in the

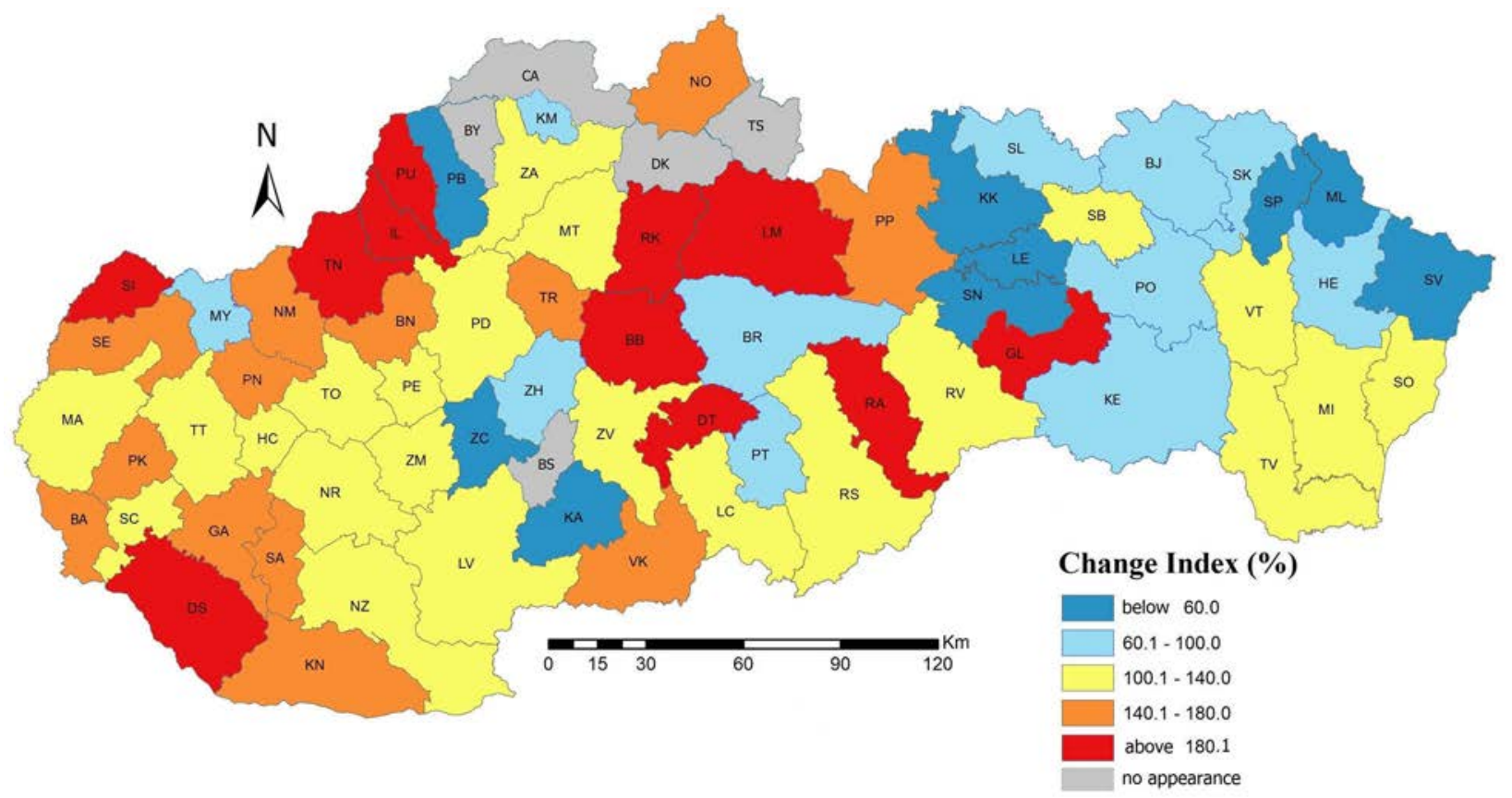

Fig. 2. Development of oilseed production in the districts of Slovakia in 2002 and 2010.

Source: regional branches of the statistical office of the Slovak Republic in Nitra, Farm Structure Census 2010, own elaboration. 


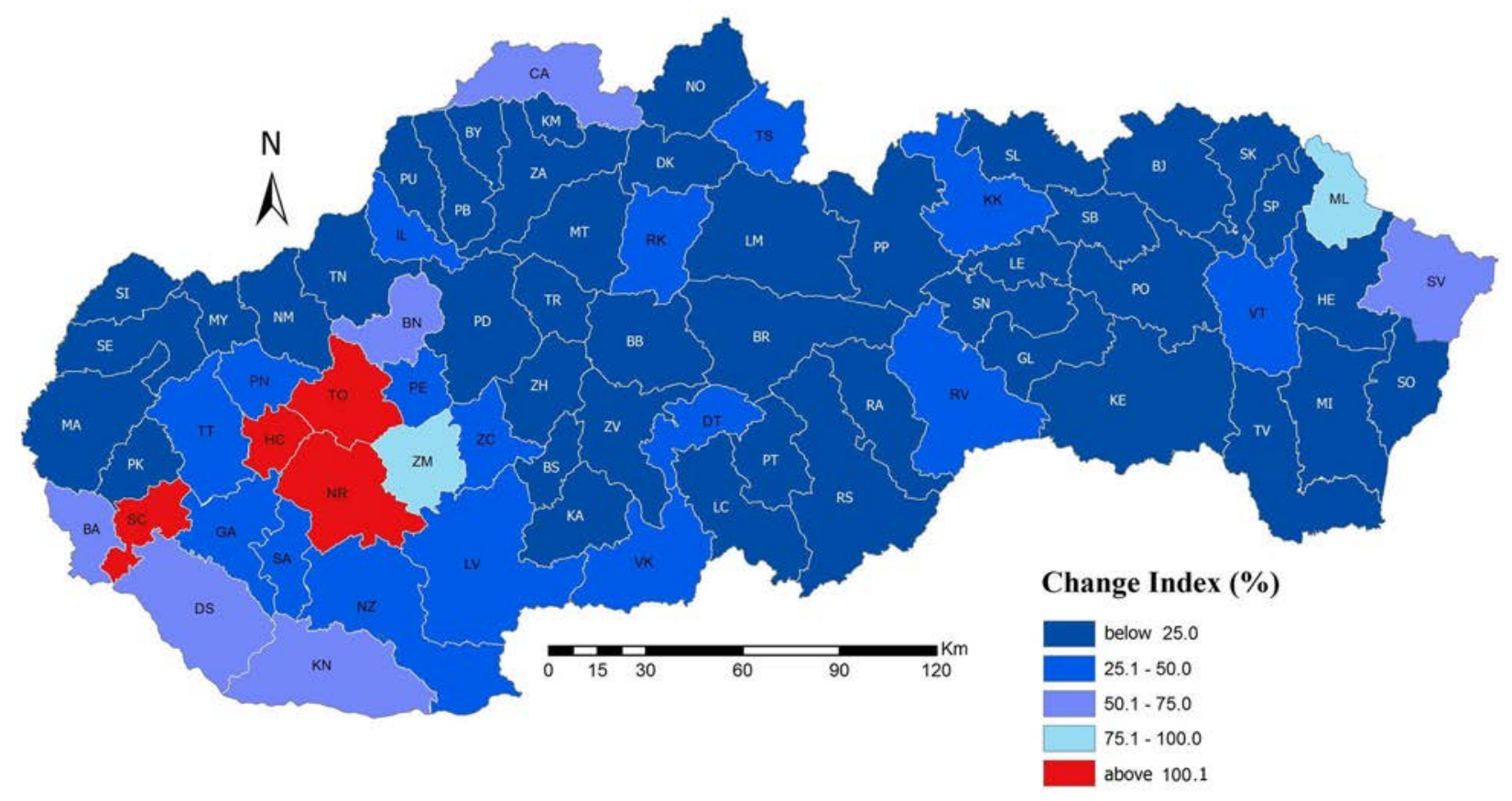

Fig. 3. Development of potato production in the districts of Slovakia in 2002 and 2010. Source: regional branches of the statistical office of the Slovak Republic in Nitra, Farm Structure Census 2010, own elaboration.

districts of Tvrdošín, Bytča, Čadca and Dolný Kubín, oilseeds are not grown at all. A decline in their production occurred especially in districts of north-eastern Slovakia (Fig. 2). In the production of oilseeds ever wider areas are occupied by rapeseed (the main crop for bio-fuel production), considering its support on the part of the EU. As a consequence, there was a drop in sunflower growing areas. Taking into account climate changes related to global warming, one may predict an expansion of oilseed growing areas into the northern parts of Slovakia at higher altitudes.

Potato production recorded the biggest decrease, of $72.57 \%$, or a drop by 400,406 tons. Slovakia was an important country in the cultivation of potatoes in the past. Currently, it becomes an importer of this crop, especially from Poland. Most of the districts recorded a decrease $(-75 \%)$, especially in the east, the central part, and in the north-west (Fig. 3). Those regions have suitable natural conditions for the production of late potatoes. An increase in production during the reference period was registered in various regions on the Podunajská nížina (the Danube Lowland). Those areas are important especially because of the production of early potatoes. Slovakia has considerable reserves in potato cultivation (planting high quality seed, improving cultivation technologies, etc.). It also has appropriate conditions for the cultivation of seed potatoes, mostly in the northern part that can be important in terms of Slovak export.

As compared with 2002, in 2010 perennial fodder crops production decreased by $5.65 \%$ (a decrease of 41,207 tons). Districts in regions strongest in agricultural terms, i.e. Podunajská nížina (the Danube Lowland), Juhoslovenská kotlina (the Southern Slovak Basin), Košická kotlina (the Košice Basin) and Východoslovenská nížina (the Eastern Slovak Lowland), suffered a decline in production. There was a slight decrease in the northern districts. A drop in the production of perennial fodder crops is influenced by the overall decline in livestock during this period. A decrease in production was registered in various districts located in central Slovakia, while the score was the best in the northern territories in the Kysuce region (Fig. 4). The estimated intensified livestock production also boosts the production of fodder crops on arable land, which affects the increase in cultivation areas of perennial fodder crops.

The reduction of agricultural subsidies from the state, which was influenced by the transformation of agriculture, the strengthening of the competitive environment in the common European market and unequal management conditions in 


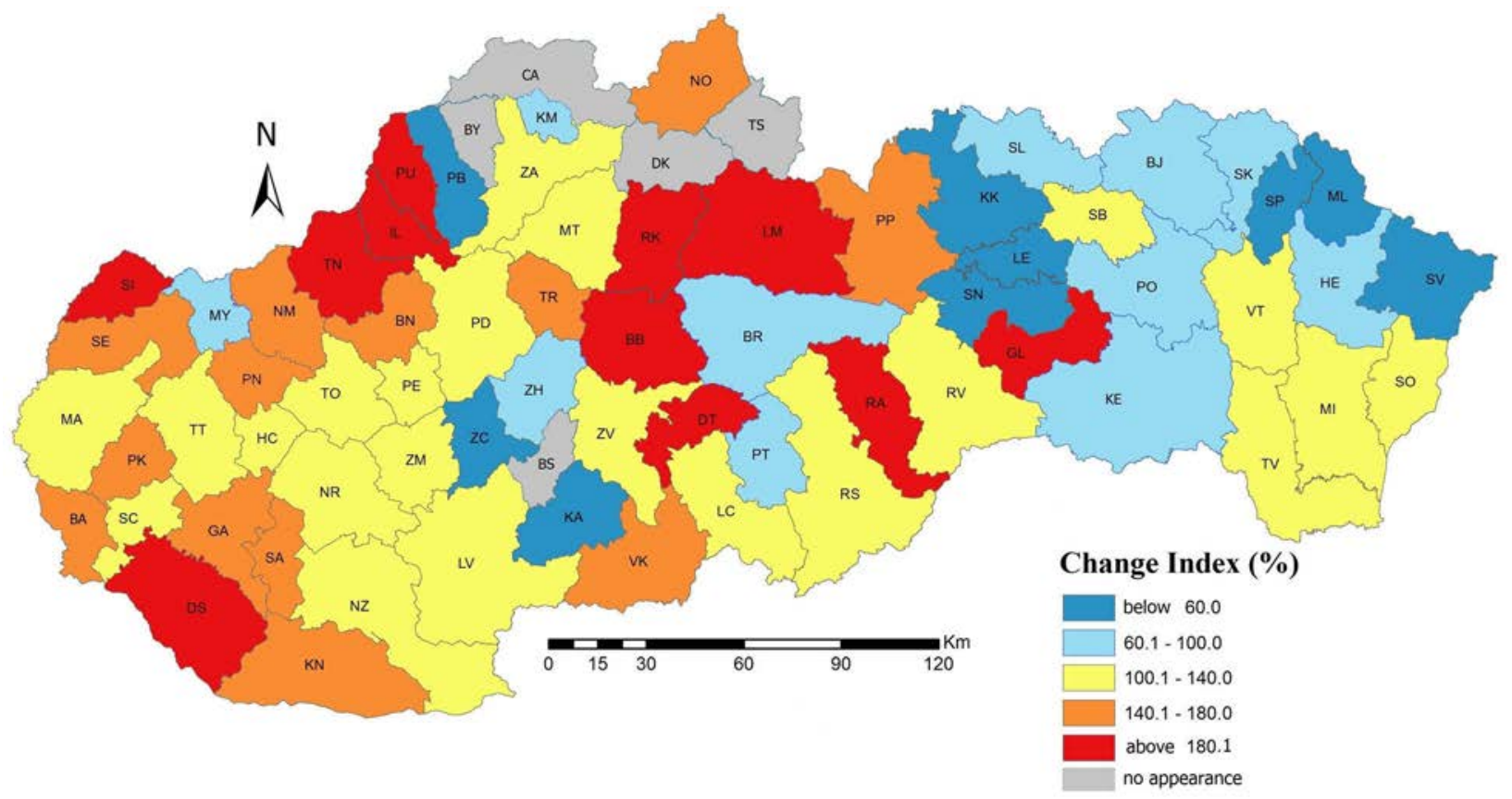

Fig. 4. Development of the production of perennial fodder crops in the districts of Slovakia in 2002 and 2010. Source: regional branches of the statistical office of the Slovak Republic in Nitra, Farm Structure Census 2010, own elaboration.

the old and the new EU member states brought about a reduction in livestock, especially pigs and cattle, causing the loss of Slovakia's self-sufficiency in the production of meat. A slight drop was recorded by several poultry units. The consumption of poultry meat is covered by national production at the level of about $60 \%$. In the case of pork meat this situation is worse, as Slovakia imports more than $50 \%$ that it needs for consumption. Taking into account the low consumption of beef meat ( $4 \mathrm{~kg}$ per capita), it is possible to export this type of meat despite its low production. A decrease in the number of livestock units may be evaluated by an indicator showing the number of livestock units per 100 ha of agricultural land. In 2002 its value was 26.80 units per 100 ha of agricultural land, while in 2010 it reached just 24.30 units. The number of cattle units in 2010, as compared with 2002, decreased by $23.15 \%$, which represents a decline of 140,710 units. This downsizing also influenced the volume of production of nuclear feeds and roughage. In terms of the change index, almost the whole of Slovakia recorded a decrease in the number of cattle units (Fig. 5). The growth in cattle units was recorded just locally in some districts located in the west and north-east. After Slovakia's accession to the EU, the number of cattle units gradually stabilised, which was positively influenced by the EU subsidy policy supporting the breeding of cattle without market milk production to maintain the landscape, especially in foothill and mountainous areas. In the parts of Podunajská nížina (the Danube Lowland), Juhoslovenská kotlina (the Southern Slovak Basin), Košická kotlina (the Košice Basin) and Východoslovenská nížina (the Eastern Slovak Lowland) changes were registered in the number of cattle units just in the period of the transformation in the early 1990s. Those are regions that have the most favourable conditions for crop production. Therefore, livestock production is less significant there, and is dominated by the breeding of pigs and poultry. On the other hand, crop production in those regions provides a sufficient fodder crop base for breeding - growing fodder crops on arable land.

The number of pig units recorded the largest decrease of all livestock species $(-55.77 \%)$. By 2010, the number of pigs decreased by 845,620 units. This significant drop is also shown by the indicator of the intensity of livestock production, the number of pigs per 100 ha of arable land. In 2002 there were 112.30 units, while eight years later this number fell to 50.70. The downward trend in the number of pigs concerned almost all districts of Slovakia (Fig. 6). The most 


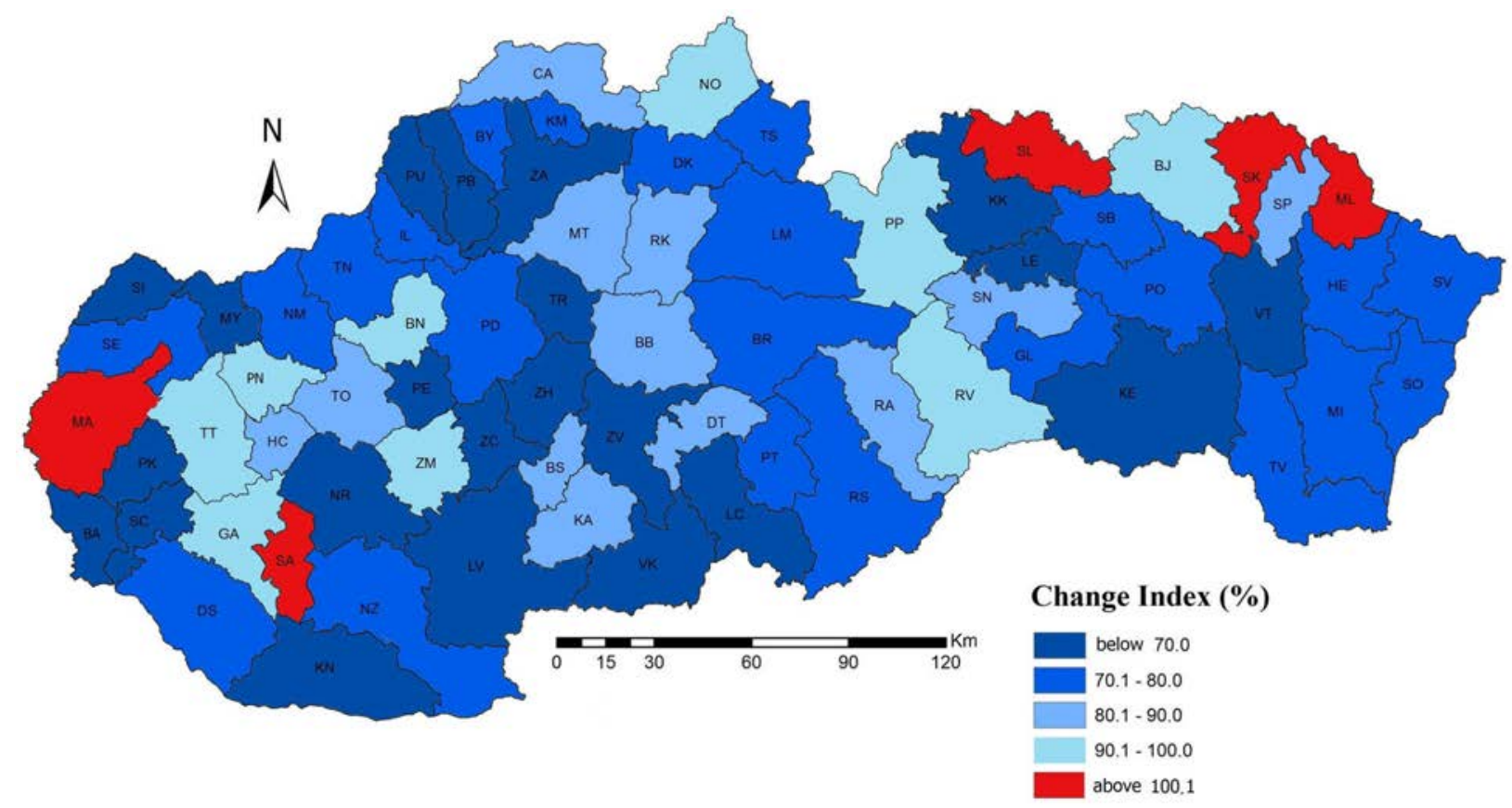

Fig. 5. Development of the number of cattle in the districts of Slovakia in 2002 and 2010.

Source: regional branches of the statistical office of the Slovak Republic in Nitra, Farm Structure Census 2010, own elaboration.

significant decrease was recorded in the central and north-eastern districts. Those are regions where the breeding of pigs is not typical. A more moderate decline is characteristic of regions in south-western, southern and south-eastern
Slovakia. Here the breeding of pigs is the most popular.

The number of poultry units decreased by $6.93 \%$, or 957,488 units. In 2002 there were $1,008.60$ units per 100 ha of arable land, while in

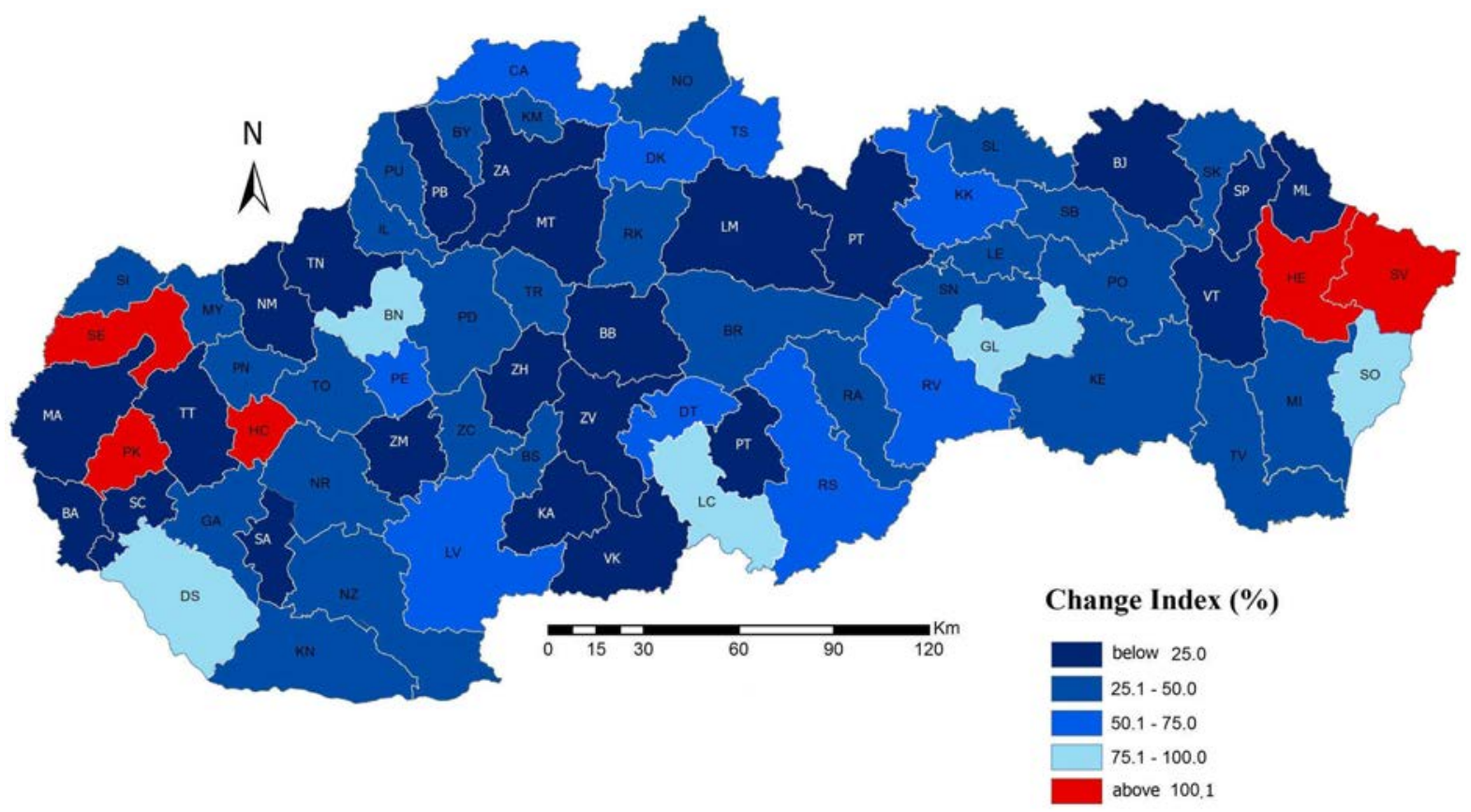

Fig. 6. Development of the number of pigs in the districts of Slovakia in 2002 and 2010. Source: regional branches of the statistical office of the Slovak Republic in Nitra, Farm Structure Census 2010, own elaboration. 


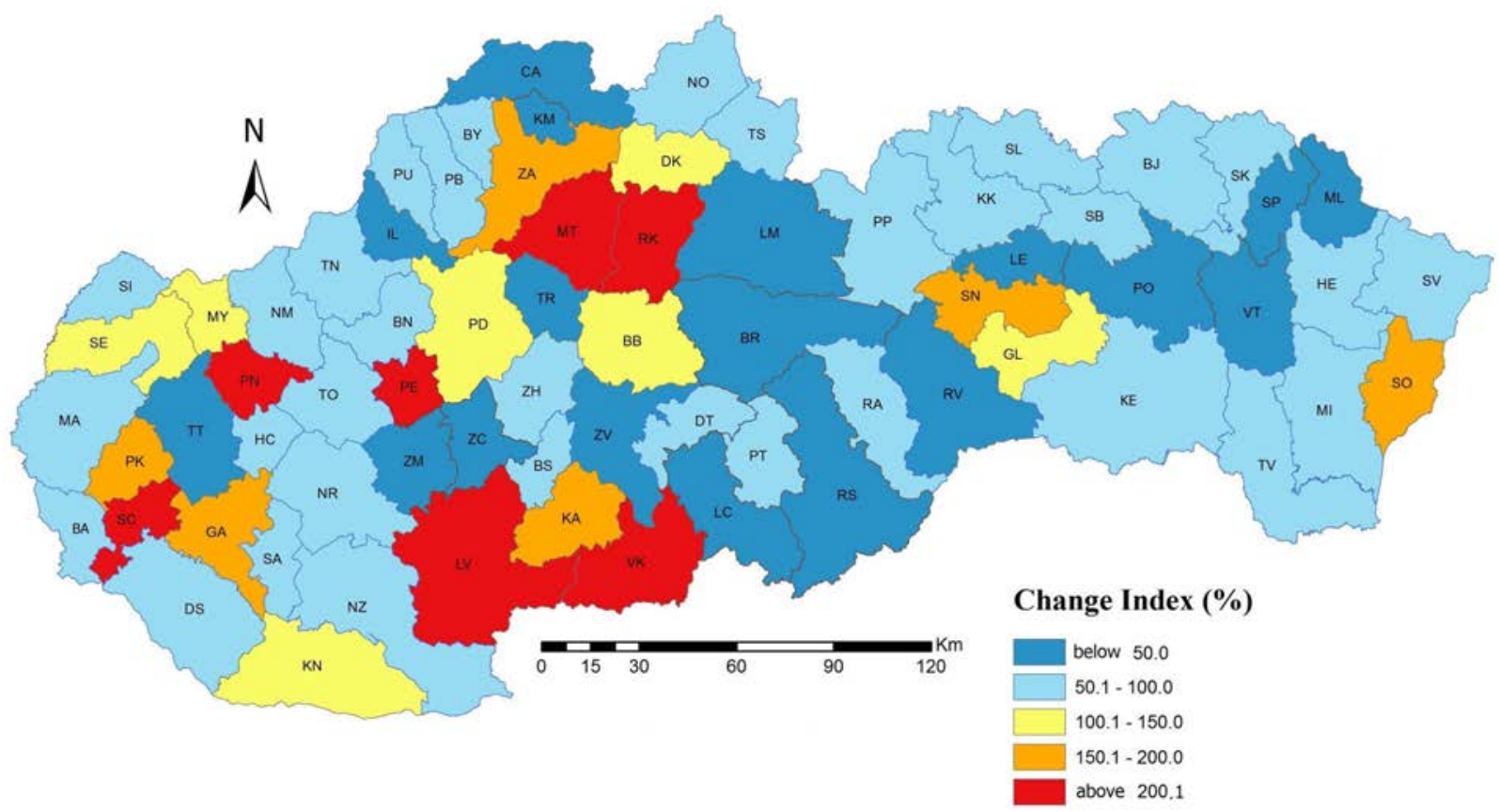

Fig. 7. Development of the number of poultry in the districts of Slovakia in 2002 and 2010.

Source: regional branches of the statistical office of the Slovak Republic in Nitra, Farm Structure Census 2010, own elaboration.

2010 this figure dropped to 959.20. Poultry meat production is weakened mainly by the policy of retail chains that prefer foreign meat suppliers over national ones that offer meat at a substantially lower price than domestic producers. A decrease of more than 50\% was typical especially of districts in central Slovakia. In general, this decline occurred mainly in regions where poultry farming is less widespread (Fig. 7).

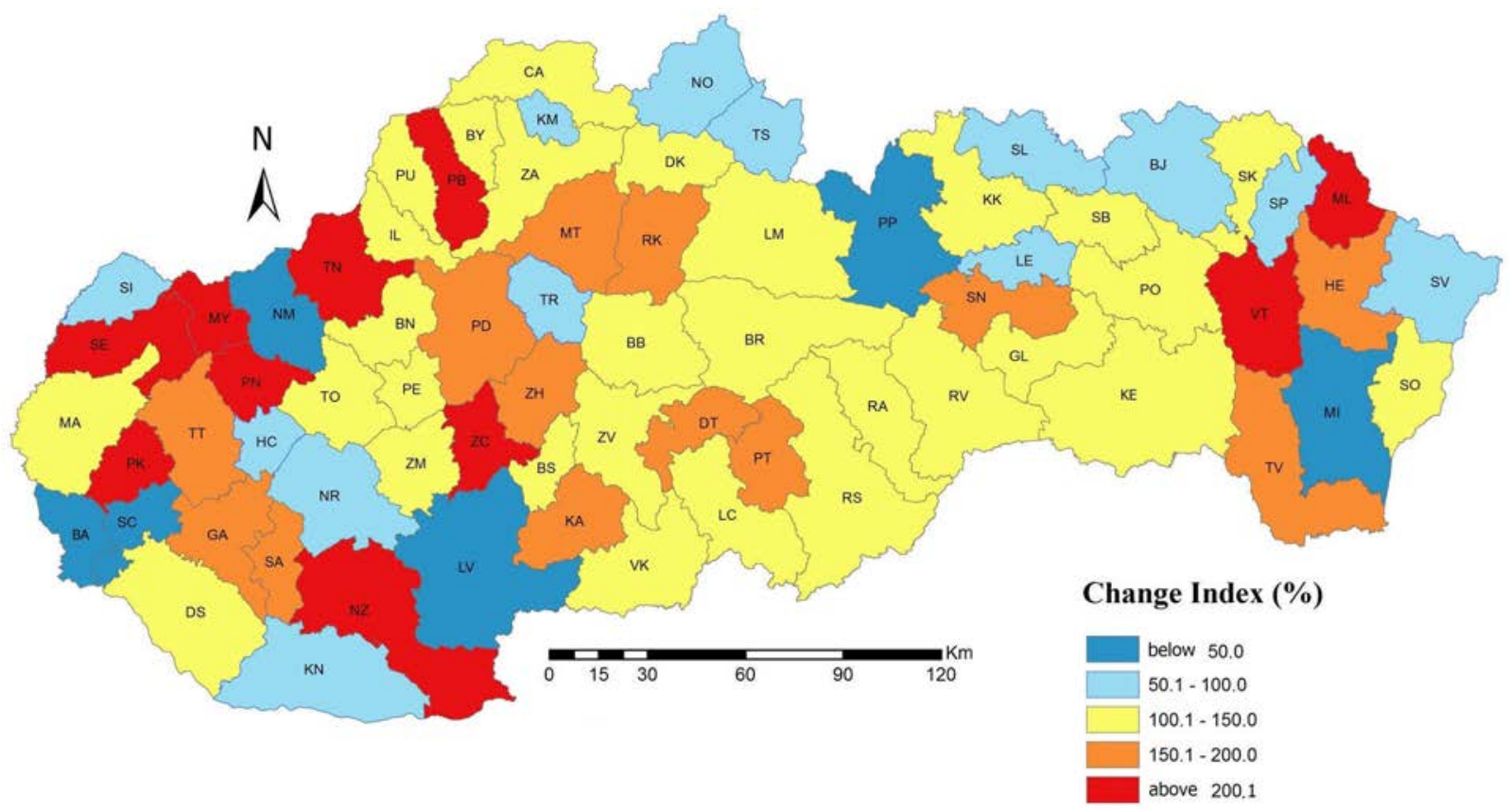

Fig. 8. Development of the number of sheep in the districts of Slovakia in 2002 and 2010. Source: regional branches of the statistical office of the Slovak Republic in Nitra, Farm Structure Census 2010, own elaboration. 
In the other species of livestock, only the number of sheep increased by $24.73 \%$, or 78,147 units. This growth can be evaluated in terms of the intensity of livestock production represented by the number of units per 100 ha of agricultural land. This indicator reached 14.00 units in 2002, but eight years later it showed 20.50 units. The increase in the number of sheep units occurred in most of the districts of Slovakia (Fig. 8). This was due to the gradual reclamation of permanent grassland as well as the promotion of livestock breeding on permanent grassland by the EU. This growth was registered mostly in districts located in western and central Slovakia, which are areas where sheep breeding is the most widespread.

In the rural areas of Slovakia and other EU member states, agriculture is a primary economic activity. The survival and maintenance of the rural population also depends on agriculture. In all EU countries, farmers keep the countryside alive and preserve their rural way of life (Common Agricultural Policy 2012). Therefore, the CAP tries to provide financial support for farmers. Many workers in agriculture, however, also engage in other activities, e.g. food processing, providing accommodation for tourists, etc. This diversification of the rural economy is also promoted by the EU through rural development. The EU seeks to prevent the depopulation of the countryside despite the fact that there are fewer job opportunities there and higher unemployment. There is still a large number of people with low human capital working in agriculture (individuals with lower qualifications, older manual workers with poor chances on the labour market, etc.) who have a low salary, too. It is highly likely that in the future there will be a reduction in the share of those low-skilled workers considering the dynamics of innovation and technological progress in agriculture. Furthermore, their working positions will be taken by younger and better-qualified workers with a higher level of human capital (Buchta 2010). Many young people consider agriculture as unattractive and therefore the number of farmers is on a decrease. In order to help young farmers in their business, they receive through the CAP some financial support for the acquisition of land, machines and further necessary equipment. The CAP also provides grants for training courses - for new as well as experienced farmers - focusing on the latest technological procedures and methods (Common Agricultural Policy 2012). One of the most popular indicators in evaluating the

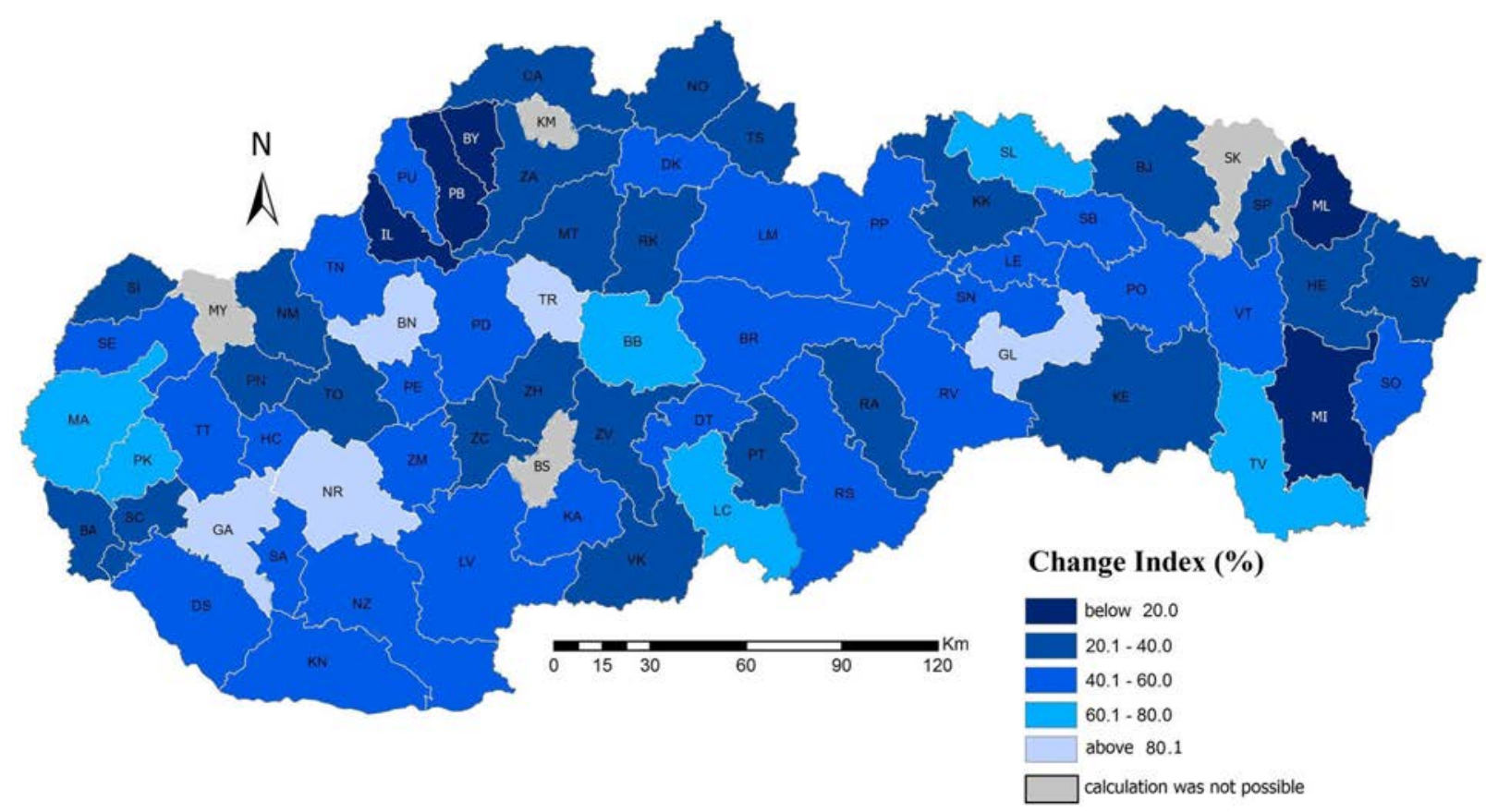

Fig. 9. Development of the number of employees in agriculture in the districts of Slovakia in the years of 2002 and 2010.

Source: regional branches of the statistical office of the Slovak Republic in Nitra, Farm Structure Census 2010, own elaboration. 
drop in agricultural employment is the share of farm workers in total employment. This indicator reached $5.99 \%$ in 2002 and dropped to $5.23 \%$ in 2004, while in 2010 it reached a mere 3.01\%, currently being under $3 \%$. The accession to the EU has not stopped this downward tendency in agricultural employment which began with the social and economic transition in the 1990s. A decrease at that time was primarily due to existential problems of agricultural workers as well as problems connected with ensuring the operation of agricultural production after the changes in the national agricultural policy. Production costs increased due to the growth of input prices (fuel, fertilisers, seeds and forage), while incomes from agricultural production declined (Falt'anová 2008).

In Slovakia there were 82,383 workers employed in agriculture, fishery, and forestry in 2002. By 2010, their number fell to 38,006 representing a decrease of $53.87 \%$. This reduction in the labour force in agriculture still continues. The reduced number of employees has also a positive impact, e.g. on growth in labour productivity as well as on a more effective use of significantly lower subsidies going to farming. In accordance with the obtained values of the change index, there is a decline in the labour force in agriculture in all districts of Slovakia (Fig. 9). The most significant drop (over 80\%) was registered in districts located in the northern regions. The decline was the lowest (under 20\%) in districts located in areas most intensively used agriculturally, on the Podunajská nížina (Danube Lowland) and Východoslovenská nížina (the Eastern Slovak Lowland). The change index was not possible to calculate because of the unavailability of data for the districts of Myjava, Banská Štiavnica, Svidník, and Kysucké Nové Mesto.

\section{Discussion}

Agriculture has two main roles - to produce food as well as to handle and cultivate the landscape. Therefore farmers use subsidies and support from the CAP for the transition to agricultural methods that are environmentally friendly, such as a reduction of chemical fertilisers and pesticides applied to crops, a reduction of the density of livestock units (number of units per 1 ha of land), the maintenance of permanent grassland in the country, keeping the aesthetic value of the countryside, etc. According to Blacksell (2010), agriculture has still a strong influence on the shaping of the country. The path of further development of agriculture is therefore a key factor for the future of the European environment. Roosel and Sepp (2010) assess agricultural land in Estonia through the adoption of agricultural and environmental policies of the EU. They focus on the effect of agriculture on the environment. While economic conditions keep improving, the negative impact on the environment is increasing. It is necessary to use environmentally friendly agricultural schemes according to the environmental needs in different types of landscape. The main aim of the agro-environmental programme is to direct agriculture to more sustainable techniques in order to avoid damage of semi-natural and natural habitats and landscape elements on farms as well as to preserve landscape biodiversity. The EU tries to maintain agriculture also in less-favoured regions, such as mountainous areas, other territories with unfavourable conditions, and those endangered by the loss of population that is essential for landscape maintenance in disadvantaged regions. In the CAP, contributions for less-favoured areas are a specific form of support in order to avoid depopulation of the countryside in marginal, peripheral and outlying European areas. Following Doucha et al. (2012), it is assumed that the depopulation can be prevented by sustainable agriculture and a vital economy which can create job opportunities in such regions. Only effective and competitive agriculture supports the viability of the rural economy and is an important element of rural activities. The goal of the Europe 2020 Strategy is especially the support of the competitiveness of Slovak agriculture, sustainable management of natural resources, and the economic development of rural areas in Slovakia (Némethová et al. 2014).

Agriculture is strongly influenced by external soil and climate conditions, and will be one of the branches that will soon be affected by climate changes related to global warming. An elongation of the vegetation period, changes in physiological conditions of crop cultivation, phenological changes as well as those in overwintering conditions, changes in soil features, etc., underline the necessity of a gradual adaptation 
and restructuring of agricultural production in Slovakia. There will also be other important tasks, such as the protection of livestock against high temperatures and the implementation of systems of livestock breeding which make it possible to reduce the impact of extreme climatic parameters (warmth and drought) on the production, health of animals, their reproduction, and the effect of breeding on air quality (Prognóza ... 2008). The climate change and the growing pressure on natural resources (especially the use of land and its change to other purposes) force farmers to produce more food from a smaller amount of natural sources. Therefore, of essential importance is support for research and innovations that bring an increase in productivity and total revenues in agriculture.

The structure and specialisation of crop production comes from the principles of sustainable development and ensuring a proper level of competitiveness in this globalised economy. Crop production will take consumers' requirements into greater consideration, hence it is estimated that there will be an increase in the number of products marked "bio", "local" and "fair trade". In sum, it will enforce further development of integrated and ecological management. The proportion of crops produced for non-food and industrial purposes will be on the increase. There will be a stabilisation of factors related to the use of non-productive effects of crop production (Prognóza ... 2008). A positive development in the structure of sown crops is a decrease in the proportion of cereals, especially a reduction in their area registered in the upland regions. The development of bioenergetics and advancing climate changes can cause their share in farmland to rise. Similarly, the cultivation of oilseeds will be on the increase for this purpose. The cultivation of perennial fodder crops has gradually stabilised in the sowing structure. Their cultivation is usually contingent on cattle breeding, which records a drop on the one hand, but cattle units are expected to stabilise on the other hand. The negative element is a decline in potato-growing areas. The majority of crops (besides perennial fodder crops cultivated at higher altitudes) are cultivated in warm lowland areas characterised by a lower amount of precipitation. Climate changes causing gradual warming will make it possible to cultivate some crops (mostly cereals) also in the northern parts of Slovakia where higher precipitation totals are typical. In the less-favoured agricultural areas non-productive functions, extensive management, the use of land for non-food purposes as well as agritourism are still preferred.

In cattle breeding an increase is expected, especially in the number of cows without market milk production. These changes will follow from turning arable land into permanent grassland and its subsequent extensive use for cattle breeding. Slovakia has a significant potential in pig breeding, with the goal of attaining complete self-sufficiency in pork production, even to the extent of exporting it abroad. The currently increased interest of consumers in poultry may support greater production of poultry for slaughter. Sheep meat arouses minimal interest on the Slovak market and its majority (especially lamb) is exported to advanced EU countries. With the support and subsidies for permanent grasslands, it is estimated that sheep breeding will be given a further boost. Together with cattle breeding, it is of irreplaceable importance in the sustainable development of the countryside in mountainous and foothill areas, and therefore its support is necessary.

The overall demographic tendency in Slovakia (a decline in the population, a rise in the average age, a decrease in productive population) will strengthen the current downward trend in agricultural employment and the rapid worsening of the age structure of workers in agriculture. The present tendency clearly shows the ageing of the farming population as well as Slovakia's getting closer to the developed EU countries in terms of employment in agriculture. The number of agricultural workers will decrease steadily, while services and business activities as well as food processing and other non-agricultural activities will develop. Supporting young farmers and ensuring continuity from one generation to another is a real challenge for rural development in all EU countries (Common Agricultural Policy ... 2012).

\section{Conclusions}

As for the production of the studied crops, we recorded significant differences in the particular regions of Slovakia in terms of the LAU I level 
(districts). Cereals are grown in all its districts since it belongs to the countries with the tradition of their cultivation. There was a decline in their production by about $20 \%$ between 2002 and 2010. A more significant decrease occurred in eastern Slovakia, while western Slovakia with its granaries is characterised by a significantly slower decline, and in some districts there was even an increase in production. Oilseeds have become a very popular crop group with great market demand (due to their wider use for nonfood purposes) and therefore their production increased by about $27 \%$. This increase took place mostly in western, southern and eastern districts, while they represent stable regions regarding oilseeds cultivation. Potato production recorded the sharpest decrease of all crops, by more than $70 \%$. It is a crop that suits the natural conditions of Slovakia, which has a tradition of its cultivation. It is a great pity that this crop slowly disappears from our fields. Slovakia is therefore dependent on the import of potatoes from abroad. There was a slight increase in production in the south-western regions, which are characterised mainly by the production of early potatoes. In other Slovak regions, we recorded a drop in production. The decline in the production of perennial fodder crops by $5.65 \%$ was related to the overall decline in livestock numbers. A more significant decrease in the production of those crops appeared in south-western and south-eastern Slovakia. As in crop production, significant regional differences were also recorded in the number of livestock units. The breeding of pigs recorded the sharpest decrease of all livestock species $(-55.77 \%)$, followed by cattle $(-23.15 \%)$ and poultry $(-6.93 \%)$. More significant reductions in the number of pig units occurred in northern and central Slovakia - regions with their lower numbers and where their breeding is not typical. The number of cattle heads fell mainly in southern and south-western Slovakia, characterised by their lower overall numbers and breeding mostly focused on milk production. The number of poultry decreased in the central and eastern or north-eastern regions, characterised by less favourable conditions for breeding of this kind of livestock. In turn, the number of sheep units increased in almost all Slovak districts between 2002 and 2010, reflecting a national increase by $24.73 \%$. The overall decline in crop and livestock production is related to an annual decline in workforce in agriculture. Compared with 2002, in 2010 there was a decrease in agricultural workers by more than $50 \%$, this decline being even more significant in the north and east of Slovakia. The most agriculturally oriented regions located in the west and south recorded a more moderate decline in agricultural employment. In the next period, the reduction in the number of people working in farming will continue. The decline will mostly concern older and low-skilled workers, and will be linked to the progressive introduction of innovations into this economic sector.

\section{References}

Bičík I. et al., 2010. Vývoj využití ploch v Česku. Česká geografická společnost', Praha.

Blacksell M., 2010. Agriculture and landscape in 21st century Europe: The post-communist transition. European Countryside 2(1): 13-24.

Buday Š. et al., 2012. Porovnanie dopadov SPP na vývoj polnohospodárskej výroby a objem zahraničného obchodu. Výskumný ústav ekonomiky pol'nohospodárstva a potravinárstva, Bratislava.

Buchenrieder G., Möllers J. (eds), 2009. Structural change in Europe's rural regions. Farm livelihoods between subsistence orientation, modernisation and non-farm diversification. Studies on the Agricultural and Food Sector in Central and Eastern Europe, Vol. 49, IAMO, Halle. Online: http:// ageconsearch.umn.edu/ bitstream/ 53334 /2/ IAMO\%20studies\%20series_vol49.pdf (accessed 18 October 2014).

Buchta S., 2010. Vývojové trendy v oblasti ekonomiky práce $\mathrm{v}$ polnnohospodárstve SR. Ekonomika polnnohospodárstva 10(3): 3-10.

Common Agricultural Policy: A partnership between Europe and farmers, 2012. Online: http://ec.europa.eu/ agriculture/cap-overview/2012_en.pdf (accessed 11 February 2015).

Csaki C. et al. (eds), 2010. Structural change in agriculture and rural livelihoods: Policy recommendations. Detailed Report, Chapter 4, Project "SCARLED" SSPE-CT-2006-044201. Online: http:// www.scarled.eu/ uploads/ media/ SCARLED_D10_2_final_2013_01.pdf (accessed 22 January 2015).

Doucha T., Štolbová M., Lekešová M., 2012. Assessment of support for farms in the Czech less favoured areas with special regards to cattle breeding. European Countryside 4(3): 179-191.

Falt'anová N., 2008. Očakávané vplyvy agrárnej politiky EÚ na vývoj polnohospodárskej výroby SR. Prognostický ústav SAV, Bratislava.

Farm Structure Census 2010 - complete results, 2012. Statistical Office of the Slovak Republic.

Holúbek I., Baco P., Buday Š., 2013. Vplyv transformácie polnohospodárstoa na diverzitu a ochranu krajiny. Univerzita Konštantína Filozofa v Nitre, Nitra. 
Kabrda J., Jančák V. 2006. České zemědělství a krajina po vstupu Česka do EU: nový institucionální rámec. XXI. sjezd České geografické společnosti. České Budějovice.

Kołodziejczak A., 2006. Agriculture and the countryside in Poland: Alternative scenarios of change. Quaestiones Geographicae 25(B): 47-52.

Kołodziejczak A., Kossowski T., 2011. Diversification of farming systems in Poland in the years 2006-2009. Quaestiones Geographicae 30(2): 49-56.

Král M., Palasová P., Svobodová H., Věžník A., 2012. Dopady SZP EU na rozvoj zemědělství v centrální části Drahanské vrchoviny. Geographia Cassoviensis 6(2): 78-90.

Kulikowski R., 2005. Agricultural problem areas in Poland, 2002. Moravian Geographical Reports 19(1): 50-60.

Marcinčáková D., 2013. Kvantifikácia regionálnej diferenciácie výkonnosti agrárneho sektora. Ekonomika polnnohospodárstoa : Economics of Agriculture 13(3): 72-84.

Marušinec J., Škriečka M., 2009. Analýza systému podpory v pôdohospodárstve. Analýzy - Argumenty - Názory. Pracovné materiály 9. M.E.S.A. 10 - Centrum pre ekonomické a sociálne analýzy, Bratislava.

Némethová J., 2009a. Agropotravinárske štruktúry okresu Nitra. Univerzita Konštantína Filozofa v Nitre, Nitra.

Némethová J., 2009b. Agroštruktúry vysokoprodukčného regiónu Slovenska / Agricultural structures of a highly productive region in Slovakia. Ekonomika pol'nohospodárstva: Economics of Agriculture 9(2): 50-58.

Némethová J., 2010. Types of agricultural enterprises in the high production region in Slovakia (sample area of the Nitra district): Typizácia vybraných agrosubjektov vysokoprodukčného regiónu Slovenska (modelové územie okres Nitra). Agricultural Economics 56(1): 25-31.

Némethová J., Dubcová A., Kramáreková H., 2014. The impacts of the European Union's Common Agricultural Policy in Slovakia. Moravian Geographical Reports 22(4): 51-64.

Prognóza a vízia vývoja Slovenského polnohospodárstva, Potravinárstva, lesníctva a vidieka, 2008. Online: http:// www.mpsr.sk/ index.php?start\&navID =2\&navID2 $=2 \&$ sID $=17 \& \mathrm{id}=657$ (accessed 8 May 2015).

Ramniceanu I., Ackrill R., 2007. EU rural development policy in the new member states: Promoting multifunctionality. Journal of Rural Studies 23(3): 416-429.

Roosel A., Sepp K., 2010. Monitoring framework for assessing changes of the Estonian rural landscape in adopting European agricultural policies. European Countryside 2(1): 42-59.

Rudnicki R., 2013. Spatial differences in the number of applications for payments under the EU Common Agricultur- al Policy submitted by agricultural holdings in Poland over the years 2002-2010. Quaestiones Geographicae 32(4): 15-31.

Shucksmith M., Thomson K.J., Roberts D., 2005. CAP and the regions: The territorial impact of Common Agricultural Policy, CABI Publishing, Wallingford (UK). Online: http:/ / books.google.at/books?id=R000DK-1cfIC\&pg=PA149\&sig=gQNd558qBEe2-_BDRqo0tzHyqNg (accessed 9 June 2014).

Spišiak P., 2011. Výskum rurálnej krajiny v posttransformačnom období na Slovensku. Geographia Cassovienssis 5(1): 93-99.

Spišiak P. et al., 2005. Agrorurálne štruktúry Slovenska po roku 1989. Geo-grafika, Bratislava.

Spišiak P., Némethová J., 2008. Agrosubjekty regiónu Nitra vo vzt'ahu k odberatel'om pol'nohospodárskych surovín. Geografický časopis 60(1): 63-87.

Střeleček F., Lososová J., Kvapilík J., 2004. Development of livestock in numbers and structure from the regional and administrative aspect. Agricultural Economics 50(2): 47-57.

Svobodová H., 2011. Vývoj zemědělské výroby v České republice pod vlivem společné zemědělské politiky EÚ. Acta regionalia et environmentalica 8(1): 15-21.

Svobodová H., Věžník A., 2011. Impacts of the Common Agricultural Policy of the European Union in the Vysočina region (Czech Republic) by the view of the farmers. Journal of Central European Agriculture 12(4): 733-743.

Uhrinčat'ová E., 2011. Effects of the Common Agricultural Policy potential scenarios after 2013 in the Slovak Republic. Agricultural Economics 57(1): 27-34.

Vaishar A., Zapletalová J., 2009. Sustainable development of rural microregions in the Czech borderland. Moravian Geographical Reports 17(4): 34-43.

Věžník A., Konečný O., 2011. Agriculture of the Czech Republic after accession to the EU: regional differentiation. Moravian Geographical Reports 19(1): 50-60.

Věžník A., Král M., Svobodová H., 2013. Agriculture of the Czech Republic in the $21^{\text {st }}$ century: From productivism to post-productivism. Quaestiones Geographicae 32(4): 7-14.

Věžník A., Svobodová H., 2012. Vývoj zemědelství kraje Vysočina pod vlivem spoločné zemědělské politiky EU. Geographia Cassoviensis 6(1): 81-92.

Zaušková L'., Midriak R., Krajčovič V., 2012. Dopady transformačného obdobia a obdobia po vstupe Slovenska do EÚ na zmeny využívania pol'nohospodárskej krajiny. Ekonomika polnohospodárstva 12(4): 98-106. 